\title{
The Influence of Firing Line Active Learning Approach on Students' Motivation in Learning Mathematics
}

\author{
Siti Lestiawati ${ }^{1}$, Rahmita Nurul Muthmainnah ${ }^{2}$ \\ $\left\{{ }^{1}\right.$ sitilestiawati@gmail.com, ${ }^{2}$ rahmita_nurul@yahoo.co.id $\}$ \\ ${ }^{1,2}$ Universitas Muhammadiyah Jakarta, Indonesia
}

\begin{abstract}
This research was carried out because of the low motivation of grade 8 students in SMPN 01 Tenjo and the conventional teacher centred method used in their mathematics classroom. The aim of this research was to identify whether there is an influence of firing line active learning approach on students' motivation in learning mathematics. This research used quasi experimental posttest only control design. The subject if this research were the students at SMPN 01 Tenjo grade 8 in two classes 8.1 and 8.2 with the total number of students are 65 students. In order to get the data, students learning motivation questionnaire used in this research. Then, t-test used to analyse the data. It was proven by the results of $t_{\text {value }}=2.043$ and $t_{\text {table }}=1.998$. $(2.043>1.998)$. It was found out that the average score of students' mathematics learning motivation in experiment class (which use firing line active learning approach) is greater than in the control classroom (that use conventional learning method). In conclusion, the firing line active learning approach influenced students' motivation in learning mathematics.
\end{abstract}

Keywords: Active Learning, Firing Line, Students' Motivation

\section{INTRODUCTION}

Education is a means in shaping a person's character with the intention of creating the quality and competitive human resources. In order to reach that goal, the cooperation from various sector including government, educational stakeholders, and family are needed. Learning mathematics is a process of interaction between the teacher and students to get new information related to mathematical knowledge, with the intention of changing the students' mindset and behaviour.

Learning mathematics is very important. Mathematics is not just a collection of numbers, symbols and formulas, which have nothing to do with the real everyday life, it is precisely that mathematics grows and develops from the daily life, moreover mathematics is able to help people in overcome the social, economic, and another routine problem [1][2]. However, in teaching mathematics, many teacher still use teacher centred method, as a result, students achievement were low and there were less active in the learning process [3]-[5].

There are many factors cause students to be passive and feel unmotivated in mathematics classroom. Those factors can come from within students or from outside students themselves, one of which is the teaching method that mostly used in mathematics tend to monotonous and 
less varied method [6]. Furthermore, students that are not given the opportunity to play an active role in learning process resulting in low motivation to learn mathematics.

From the conditions above, the question arises how to make students more active in the mathematics learning process with a pleasant and reciprocal learning atmosphere, so that the students are motivated in learning mathematics. Therefore, in the learning process requires learning strategies that are student-centred or not conventional ones [3][4]. There are many learning strategies that focus on students that will have an impact on increasing student motivation in learning mathematics in the classroom alternately. Active learning strategy as a learning system through active ways of learning towards students' independent learning and also a learning approach where students are directly involved in doing something and think about what they are doing in class, is one of it [9][10]. In this research, the researcher proposes one active learning strategies that can be used in mathematics crassroom, the firing line method. Firing line (line of fire) is the format of quick movements that can be used for various purposes such as testing and role play, it offers continuously couple spins, learners have the opportunity to respond quickly to the questions posed or types of challenges that other [11]. Firing line is one of the active learning strategies that takes advantage of study groups to maximize learning [9].

A research about firing line strategy was conducted by Jawara [7] show that learning by the firing line method is more effective than other active learning strategy. Maharani [12] give the result of hypothesis testing which shows the students' ability in problem solving which is treated by firing line approach is higher than the ones treated by conventional learning strategy. Based on the above background, the researchers are interested in conducting research titled : The Influence of Firing Line Active Learning Approach on Students' Motivation in Learning Mathematics.

Firing line approach is an approach that is designed to demostrate the pair rotating in the formation of two rows facing where students can test each other by asking questions to their friend besides. Students who get the question should answer the questions in a limited time [13]. In addition, firing line method is a fast movement that can be used for various purposes such as testing and role playing. This method includes continuously rotating pair. Learners have the opportunity to respond quickly to the questions posed or another type of challenge. A firing line active learning approach is let the students getting more roles in the form of agile quick activities, full of enthusiasm, and also has a goal so that students can easily understand the material that has been delivered to achieve learning objectives [13][14]. Students get the opportunity to respond quickly, this strategy is used to find out how much the response or feedback from students about the material taught by the teacher at the time of giving the material, thus provide the students to play an active role in learning activities.

\section{RESEARCH METHOD}

This research was conducted in SMPN 01 Tenjo which located at Jalan Raya Tenjo Km. 02 Kecamatan Tenjo Kabupaten Bogor. The method used in this research was quasi experimental post-test only control design. The subjects of this research are 8 grade students of class 8.1 and 8.2, amounting to 65 students all. This research design consist of two groups, the first one was the experimental class in which the firing line active learning were implemented and the second one was the control class which used conventional ones [15] [16]. 
Table 1 Research Design

\begin{tabular}{|l|c|c|}
\hline \multicolumn{1}{|c|}{ Groups } & Treatment & Posttest \\
\hline Experimental class (R) & $\mathrm{P}$ & $\mathrm{O}$ \\
\hline Control class (R) & & $\mathrm{O}$ \\
\hline
\end{tabular}

$\mathrm{P} \quad$ : the treatment using the firing line active learning approach

$\mathrm{O}$ : the questionnaire were given for both groups

The independent variable of this research was the firing line active learning approach (written as X), while the dependent variable was students' motivation in learning mathematics (written as Y). The instrument used in this research was students' motivation in learning mathematics questionnaire that consist of 29 valid statements.

\section{RESULTS AND DISCUSSION}

The instrument validation result show that from the total number of 44 statements, 29 statements are valid, in which its t-count was greater than or equal to the t-table which equal to 1.988. Furthermore, from the reliability test showed $\alpha=0.988$ which greater than 0.60 . As a result, the students' motivation in learning mathematics questionnaire was reliable and could be used as a research instrument.

\section{Normality Test}

Chi-square test was used in this research to test the normality of its population. The result of the test as shown in table below:

Table 2 Normality Test

\begin{tabular}{|l|c|c|c|c|}
\hline \multicolumn{1}{|c|}{ Class } & $\begin{array}{c}\text { Number of } \\
\text { Data }\end{array}$ & $\chi^{\mathbf{2}}$ value & \multirow{2}{*}{$\chi^{\mathbf{2}}$ table } & Result \\
\hline Experimental class & 33 & 6.124 & \multirow{2}{*}{7.814} & Normally distributed \\
\cline { 1 - 3 } Control class & 32 & 4.704 & Normally distributed \\
\hline
\end{tabular}

As shown in table 2 above, $\chi^{2}$ value of the experimental class is equal to 6.124 and the $\chi^{2}$ table is equal to 7.814 . Since $\chi^{2}$ value $<\chi^{2}$ table, it means that the population of the experimental class was normally distributed. Similar to the experimental class, the $\chi^{2}$ value of the control class is equal to 4.704 which is less than the $\chi^{2}$ table that means that the population of the control class was also normally distributed.

\section{Homogeneity Test}

The next is step is the homogeneity test by using Fisher test. This test used to find out whether the data collected has a homogeneous variants or not. The calculation of homogeneity test are as follows: 
Table 3 Homogeneity Test

\begin{tabular}{|l|c|c|c|c|}
\hline \multicolumn{1}{|c|}{ Class } & Number of Data & Mean & Standard Deviation & Variance \\
\hline Experimental class & 33 & 87.333 & 8.324 & 69.292 \\
\hline Control class & 32 & 82.875 & 9.291 & 85.661 \\
\hline
\end{tabular}

$F_{\text {value }}=\frac{\text { variance }_{1 \text { (greater })}}{\text { variance }_{2(\text { smaler })}}=\frac{85.661}{69.292}=1.236$

$F_{\text {table }}=F_{\alpha}\left(\frac{d f_{1}=n_{1}-1}{d f_{2}=n_{2}-1}\right)=F_{0.05}\left(\frac{d f_{1}=33-1}{d f_{2}=32-1}\right)=F_{0.05}\left(\frac{32}{31}\right)=1.816$

Since the $F_{\text {value }}$ is less than $F_{\text {table }}$, then the variance of both classes were homogeneous.

\section{Hypothesis Test}

The first hypothesis test used t-test. This test used to see was there any influences between firing line active learning approaches to students' motivation in learning mathematics. Null Hypothesis $\left(\mathrm{H}_{\mathrm{o}}\right)$ of this test stated there is no influences between firing line active learning approaches to students' motivation in learning mathematics. While the Alternative Hypothesis $\left(\mathrm{H}_{\mathrm{a}}\right)$ stated there is influences between firing line active learning approaches to students' motivation in learning mathematics.

Table 4 T-test Result

\begin{tabular}{|l|c|c|c|c|c|c|}
\hline \multicolumn{1}{|c|}{ Class } & Number of Data & Score & Mean & $\boldsymbol{t}_{\text {value }}$ & $\boldsymbol{t}_{\text {table }}$ & Conclusion \\
\hline Experimental class & 33 & 2882 & 87.333 & \multirow{2}{*}{2.043} & \multirow{2}{*}{1.998} & $\mathrm{H}_{\mathrm{o}}$ rejected \\
\hline Control class & 32 & 2652 & 82.875 & &
\end{tabular}

From the table 4 above, the result of $t_{\text {value }}$ and $t_{\text {table }}$ with significance level $\alpha=0.05$ and degree of freedom $(\mathrm{df})=63$ are 2.043 and 1.998. Since $t_{\text {value }}$ is greater than $t_{\text {table }}$ then the null hypothesis was rejected, which means that there is influences between firing line active learning approaches to students' motivation in learning mathematics.

Next, statistics hypothesis test used to get information about which class that the mean of students' motivation in learning mathematics are greater. Null Hypothesis $\left(\mathrm{H}_{\mathrm{o}}\right)$ of this test stated the mean of students' mathematics learning motivation in experimental class is less than or equal to in the control class. While the Alternative Hypothesis $\left(\mathrm{H}_{\mathrm{a}}\right)$ stated the mean of students' mathematics learning motivation in experimental class is greater than in the control ones.

Table 5 Statistic Hypothesis

\begin{tabular}{|l|c|c|c|}
\hline \multicolumn{1}{|c|}{ Class } & Number of Data & Score & Mean $(\boldsymbol{\mu})$ \\
\hline Experimental class & 33 & 2882 & $\mu_{1}=87.333$ \\
\hline Control class & 32 & 2652 & $\mu_{2}=85.875$ \\
\hline
\end{tabular}


From table 5 above, it can be seen that $\mu_{1}=87.333$ is greater than $\mu_{2}=85.875$. It means that the mean of students' mathematics learning motivation in experimental class is greater than in the control ones.

\section{CONCLUSIONS}

As the objective of this research is to identify whether there is an influence of firing line active learning approach on students' motivation in learning mathematics, the t-test used to analyse the data resulting $t_{\text {value }}=2.043$ and $t_{\text {table }}=1.998$. Since $t_{\text {value }}$ is greater than $t_{\text {table }}$ so the alternative hypothesis $\left(\mathrm{H}_{\mathrm{a}}\right)$ was accepted while the null hypothesis $\left(\mathrm{H}_{\mathrm{o}}\right)$ was rejected. As a conclusion, there are influence the firing line active learning approach influenced students' motivation in learning mathematics. It can be seen from result of the mean of students' motivation in experimental class which was greater than in the control class.

\section{REFERENCES}

[1] M. Abdurrahman, Anak Berkesulitan Belajar (Teori, Diagnosis, dan Remediasinya). Jakarta: PT. Rineka Cipta, 2012.

[2] U. Suwanjal, "Pengaruh Penerapan Pendekatan Kontekstual Terhadap Kemampuan Berpikir Kritis Matematis Siswa SMP," AKSIOMA J. Math. Educ., vol. 5, no. 1, pp. 6167, Jun. 2016.

[3] V. . Kartini, "Peningkatan Kemampuan Pemahaman Matematikdan Sikap Positif terhadapMatematika Siswa SMP Nasrani 2 Medan Melalui Pendekatan Possing,” J. Saintech, vol. 6, no. 4, 2014.

[4] A. Murizal, Yarman, and Yerizon, "Pemahaman Konsep Matematis dan Model Pembelajaran Quantum,” J. Pendidik. Mat., vol. 1, no. 1, 2012.

[5] V. Utari, "Peningkatan kemampuan pemahaman konsep melalui pendekatan PMR dalam Pokok Bahasan Prisma dan Limas," J. Pendidik. Mat., vol. 1, no. 1, 2012.

[6] A. Sahrudin, "Implementasi Strategi Pembelajaran Discovery Untuk Meningkatkan Kemampuan Pemecahan Masalah Matematis Dan Motivasi Belajar Siswa SMA," JUDIKA (JURNAL Pendidik. UNSIKA), vol. 2, no. 1, Nov. 2014.

[7] D. S. Jawara, "Perbandingan Model Pembelajaran Aktif Strategi The Firing Line dan Index Card Math Terhadap Hasil Belajar Siswa Pada Standar Kompetensi Menerapkan Dasar-dasar Elektronika di SMK Negeri 1 Driyorejo Gresik," J. Pendidik. Tek. Elektro, vol. 2, no. 3, pp. 1041-1048, 2013.

[8] R. dkk Fitri, "The Firing Line Pada Pembelajaran Matematika Siswa Kelas XI IPS SMA Negeri 1 Batipuh," J. Pendidik. Mat., vol. 3, no. 1, pp. 18-22, 2014.

[9] Z. E. Dadach, "Quantifying The Effect Of An Active Learning Strategy On The Motivation Of Students," J. Eng. Educ., vol. 29, no. 4, pp. 1-10, 2013.

[10] E. Siregar and H. Nara, Teori Belajar dan Pembelajaran. Bogor: Ghalia Indonesia, 2010 .

[11] M. L. Silberman, 101 Cara Belajar Siswa Aktif. Bandung: Nusamedia dan Nuasnsa Cendekia, 2013.

[12] A. A. I. D. Maharani, I. M. Sugiarta, and I. P. P. Suryawan, "Pengaruh Strategi Active Learning Type Firing Line Terhadap Kemampuan Pemecahan Masalah Matematika Siswa Kelas Vii SMP Negeri 3 Singaraja," J. Pendidik. Mat. Undiksha, vol. 3, no. 1, Aug. 2015.

[13] M. L. Silberman, Active Learning. New York, 2012. 
[14] M. L. Silberman, 101 Cara Pelatihan dan Pembelajaran Aktif. Jakarta: PT Indeks, 2010.

[15] Sugiyono, Metode Penelitian Kuantitatif, Kualitatif, dan R\&D. Bandung: Alfabeta, 2013.

[16] N.K. Juliantari, I.K. Sudarsana, N.K. Sutriyanti, I.N.T. Astawa, I.D.A.H. Putri, and K. Saddhono. "Educational Games Based in Information Technology as Innovation Evaluation Activity in Learning." In IOP Journal of Physics: Conference Series, vol. 1114 no. 1, p. 012041. IOP Publishing, 2018. 